\title{
Examining the Intrapreneurship Drivers and Strategy: Case Study of Property Services in Indonesia*
}

\author{
Pusfitalisya AZIS', Muhammad Taufiq AMIR ${ }^{2}$
}

Received: September 01, 2020 Revised: October 26, 2020 Accepted: November 05, 2020

\begin{abstract}
This study examines the drivers and implementation of intrapreneurship strategy in a property service company. Using a qualitative case study approach, the study interviewed four managers involved in related intrapreneurship initiatives. The data was validated by an expert and a practitioner from a different company. The implementation of the company's intrapreneurship strategy is limited to improving new ways of working and developing products and services. However, business development and the creation of new business models are still limited. From several intrapreneurship driving factors, it was observed that the company practices are considered adequate with regard to top management support, leadership, flexibility in carrying out work, as well as in fairly harmonious arrangements for ongoing business relationships with the intrapreneurship projects. On the other hand, human resources with entrepreneurial behavior are still minimal. Similarly, the driving factors in reward and training that promote entrepreneurial behavior are also considered to be insufficient. The application of intrapreneurship as a strategy requires understanding and commitment from all parties in the organization. This study provides insight into the Indonesian context and proposes that intrapreneurship initiatives are less likely to succeed if they are not supported by developing a more systematic entrepreneurial mindset, behavior, and culture.
\end{abstract}

Keywords: Intrapreneurship, Management Support, Business Development, Flexibility, Entrepreneurial Behavior

JEL Classification Code: M10, M13, M16, M19

\section{Introduction}

Intrapreneurship has many definitions, ranging from those referring to facilitating innovation in a company to organizational reform that increases its ability to compete and take risks by adding new businesses (Yang, Narayanan, \& Zahra, 2009). As a strategy option, intrapreneurship seems

\footnotetext{
*Acknowledgements:

This paper is based on research that was funded by the Ministry of Education and Culture of Indonesia under the Grant of Master Thesis Research no: 104/SPK/LPP-UB/III/20

${ }^{1}$ First Author. Master in Management, Faculty of Economics and Social Science, Universitas Bakrie, Indonesia. Email: pusfitalisya@gmail.com ${ }^{2}$ Corresponding Author. Head of Program, Department of Management, Faculty of Economics and Social Science, Universitas Bakrie, Indonesia [Postal Address: Universitas Bakrie, Plaza Festiva, Jl. HR Rasuna Said, Kav C-22, Jakarta Selatan 12920, Indonesia] Email: taufiq.amir@bakrie.ac.id Non-Commercial License (https://creativecommons.org/licenses/by-nc/4.0/) which permits unrestricted non-commercial use, distribution, and reproduction in any medium, provided the original work is properly cited.
}

to be increasingly necessary for organizations due to changes that occur in consumers in addition to competition that is increasingly dynamic and full of challenges (Amir, 2017; Jumasseitova \& Potluri, 2020). Even though companies must face the challenges of environmental change, with intrapreneurship and developing new businesses, companies can take advantage of the opportunities and use them as sources for sustainability.

New business development involves two forms: internal and external (Sharma \& Chrisman, 2007). The first occurs when business development becomes part of an existing structure and is semi-autonomous, whereas the second involves factors outside the existing structure. Both internally and externally, business development can be linked to the parent company's core competencies or beyond these competencies. This concept is essential for achieving the goal of maintaining a competitive advantage.

Continuing competitive advantage through business renewal and development is in line with the concept of strategic entrepreneurship; that is, the identification and exploitation of opportunities while creating and maintaining a competitive advantage (Ireland, Hitt, \& Sirmon, 2003). Companies consider 
undertaking strategic entrepreneurship when innovating the corporate strategy, product offerings, markets served, organization structure, processes, and capabilities (Kuratko \& Audretsch, 2009). Such entrepreneurship is characterized by strategic renewal, lasting regeneration, realignment of the business domain, organizational rejuvenation, and business model reform (Covin \& Miles, 1999).

New variations on the definition of intrapreneurship or corporate entrepreneurship continue to evolve. Phan et al. (2009) proposed expanding this definition to include joint ventures and spinoffs at companies or colleges. Directing units or divisions to develop more flexibility in creating organizational structures is also included in this definition.

Through organizational and leadership factors, the success of an organization's intrapreneurship can vary because of different intentions, goals, scales, and resources (North, 2015). To be successful, an intrapreneur must have several factors conducive to effective development, such as top management support, the condition of the human resources, and the provision of suitable rewards (Alpkan et al., 2010). Companies are always expected to have the ability to build and promote these factors.

One company that seeks to implement intrapreneurship in business development and growth is the PVI group of companies, an integrated property service provider in Indonesia. PVI has three subsidiaries: property management, facility management, and parking management. PVI is a sub-holding of a group of companies in the property business (landed house, apartment).

Top management often suggests that intrapreneurship should be one of its strategies, but the outcomes are still far from expected. Preliminary discussion with employees reveals that one of the problems is the inactivity of employees who lack entrepreneurial behaviors. Development efforts made by companies are often hampered, whereas companies need to take advantage of current business opportunities and offer something different from those already provided by their competitors.

There are two intrapreneurship projects currently carried out by PVI. First, developing new markets for existing services within the group; second, in the form of technology development initiatives for internal business processes, which will then be developed as new products or services. Intrapreneurship suggests that established organizations must experiment with a new management model, including the organizational structure that encourages innovation (Morris, Kuratko, \& Covin, 2011). It is challenging to manage relationships with newly established companies in the context of intrapreneurship, including arranging the hierarchy with an ongoing company. Managers must understand that a new company needs to be managed in a manner that differs from the current company's operations (Amir, 2017).
Studies on the implementation of intrapreneurship strategy are still overlooked in Indonesia. Furthermore, most of the studies in this field have a Western context. Analyzing the property services industry within the Indonesian context can provide a unique explanation of how intrapreneurship can function. Managers in various industries need practical models to reference. Academically, such studies can encourage researchers to contribute further to the strategic management field or intrapreneurship, particularly in the context of organizations in Indonesia. This study evaluates what driving factors have involved facilitating the intrapreneurship strategy of PVI and suggests appropriate models as a reference for other industries. It contributes to the science of strategic management and entrepreneurship and is expected to offer an effective strategy for practitioners.

\section{Literature Review}

\subsection{Individual Factor in Intrapreneurship}

Since Pinchot (1985) offered intrapreneurship ideas, this concept has been continually evolving, and individual factors are the key to its success. According to Dess et al. (1999), intrapreneurship is a process where an individual or team creates a new business, revitalizes a company or creates product/service innovation. Intrapreneurship also requires managers to explore and expose their knowledge as effectively as possible (McGrath \& McMillan, 2000). There is an overlap between the concept of entrepreneurial behavior and innovative behavior, such that, both should be understood simultaneously to explain the intrapreneurship process (Amir, 2015). The successful figure of an intrapreneur or innovator showing entrepreneurial and innovative behavior can facilitate companies to find new business models that can become new sources of excellence. Wolcott and Lippitz (2010) assert that the critical value of intrapreneurship is that it deals with the process of creating new value for customers and organizations by changing the dimensions of the business system. Intrapreneurship is the key to business organizations that aspire to grow.

Intrapreneurship can effectively foster the progress of an organization if managers can manage employee motivation to grow and develop (North, 2015). This view makes sense because the drive to grow by generating new approaches or building new businesses is created at the individual level. As is often found, creativity or innovation typically begins with an individual's character (Choi \& Price, 2005). Apart from the characteristics of the individuals involved, personal factors such as propensity to risk-taking, desire for autonomy, need for achievement, goal orientation, and internal locus control also explain the intention to become an 'employee intrapreneur'. 


\subsection{Individual Factor in Intrapreneurship}

The study of Hornsby et al. (2009) is frequently referred to in discussing the driving factors for intrapreneurship. Among the driving factors, the factors that stand-out are organizational structure, human resources management, top management support, rewards, and risk-taking.

\subsubsection{Organizational Structure}

The organizational structure and specific relationship mechanisms between divisions can support intrapreneurship. Because intrapreneurship or innovation involves new things, the decision-making process is often a concern when shaping the organizational structure. Amir (2017) suggests the need for existing staff allocation arrangements for intrapreneurship projects without disrupting ongoing business activities to determine organizational structuring.

Govindarajan and Trimble (2010) also emphasize the necessity to share responsibility among employees as members of the intrapreneurship team and responsibilities as existing employees. At the same time, management must select members of the intrapreneurship team appropriately to ensure high performance. This attempt also implies using existing resources, the required competencies, networks, technology, or market of existing organizations.

Sound management of how the system is created with this organizational arrangement determines the success of intrapreneurship (Burgers et al., 2009). Many studies have considered that intrapreneurship initiatives require emphasizing the need to provide autonomy for new companies and ensuring that the parent company shares its knowledge and other resources through integration mechanisms.

\subsubsection{Human Resources Management}

Although the aspects of personality and individual capacities are essential, human resource management (HRM) is another determining factor in the success of intrapreneurship (Phan et al., 2009). General HRM practices such as recruitment, development, and compensation should also be modified when implementing intrapreneurship. For instance, characteristics or employee behavior that the organization needs to achieve intrapreneurship success demands a specific recruitment strategy.

Companies need talents who are creative and innovative, dare to take risks, long-term thinkers, focused on results, flexible to change, able to work well together, independent, responsible, and have the ability to share the organization's intrapreneurship knowledge (Montoro-Sanchez \& Ribeiro Soriano, 2011). The practice of staffing sometimes needs to be entrepreneurial in the sense that it is flexible and not rigid with conventional silo-based rules.
In a property company, for example, an HR manager who has good leadership is challenged to direct a new business development project (Amir, 2017). Supporting learning from management and the appetite for learning itself is also highly important because intrapreneurs deal with new things. HRM practices that encourage enhancing knowledge, skills, and abilities to support intrapreneurship initiatives are fundamental. Furthermore, to ensure that they receive adequate support from various parties, intrapreneurs need political skills (Tang et al., 2015).

\subsubsection{Top Management Support}

As in every strategy, in intrapreneurship, leadership also plays a critical role. Top management is most determined to support entrepreneurial organizations and drive change (Do et al., 2020). This support is particularly necessary during the early stages of developing a new company or initiative, not only in the form of suggesting ideas, but also political support (Hornsby et al., 2009). Entrepreneurial top management is a type of leadership that can inspire others to manage resources to encourage opportunity and advantageseeking behavior (Covin \& Slevin, 2008).

Kuratko (2007) offer a top management support model that makes organization entrepreneurial by: 1) promoting a clear and consistent entrepreneurial vision; 2) giving rewards and recognition to the employees involved; 3) reducing the organizational hierarchy structure; 4) encouraging employees to take the initiative to experiment in creating or developing a business innovation; and 5) increasing employee empowerment in making company policies.

Logahan and Jerry (2014) propose that top management should provide training or discussions with employees to build a shared understanding of appropriate intrapreneurship activities. Another area of support is to encourage employee career development. In this case, it is encouraged to be more entrepreneurial and consider the business as a whole, no longer limited to particular divisions or departments. To succeed, top management should also facilitate employees in gaining access to resources, such as access to information or financial sources. Of course, this strategy has implications for determining rewards for employees involved in intrapreneurship projects.

\subsubsection{Reward System}

Employees are keen to become involved in intrapreneurship initiatives by considering specific reward arrangements (Hornsby et al., 2009). Because the challenges and risks are not small, particularly for those who lead an initiative, employees expect to receive reward packages that differ from those provided to regular employees. Therefore, Sathe (2007) proposes that, compared to ordinary professionals, intrapreneurs should be rewarded differently. 
On the other hand, Hornsby et al (2009) found that intrapreneurs tend to be motivated by regular pay packages, bonuses, profit shares, job security, and increasing responsibilities. In many cases, rewards are sometimes used to attract high potential in the form of attractive positions and compensation. Being the CEO of a newly founded company, for instance, is a special reward for someone who may initially only lead a division. The compensation may be in the form of a proportion of shares. There are generous parent companies that give their intrapreneurs the freedom to design their benefit packages for themselves and their team members (Amir, 2017).

\subsubsection{Tolerance with the Risk}

Tolerance for risk and failure is one of the main aspects conducive to entrepreneurship (Alpkan et al., 2010). When top leaders provide this tolerance, it means that they give trust, and in time, intrapreneurs are motivated to carry out their initiatives (Fakir \& Jusoh, 2020). They know the potential for failure exists, but at the same time, they can hope that their superior will fairly see the consequences. This approach increases the likelihood that someone works optimally, looking more at opportunities than threats when failures occur. Similarly, intrapreneur employees will feel that in the end, their superior will share responsibility when a problem arises (Amir, 2017). An intrapreneur is expected to analyze, make judgments, and rely on his/her intuition appropriately for the innovation to be successful. North (2015) asserts that successful intrapreneurs tend to plan particularly well, which aims to minimize the level of risk so that intrapreneurs can be said to control their future.

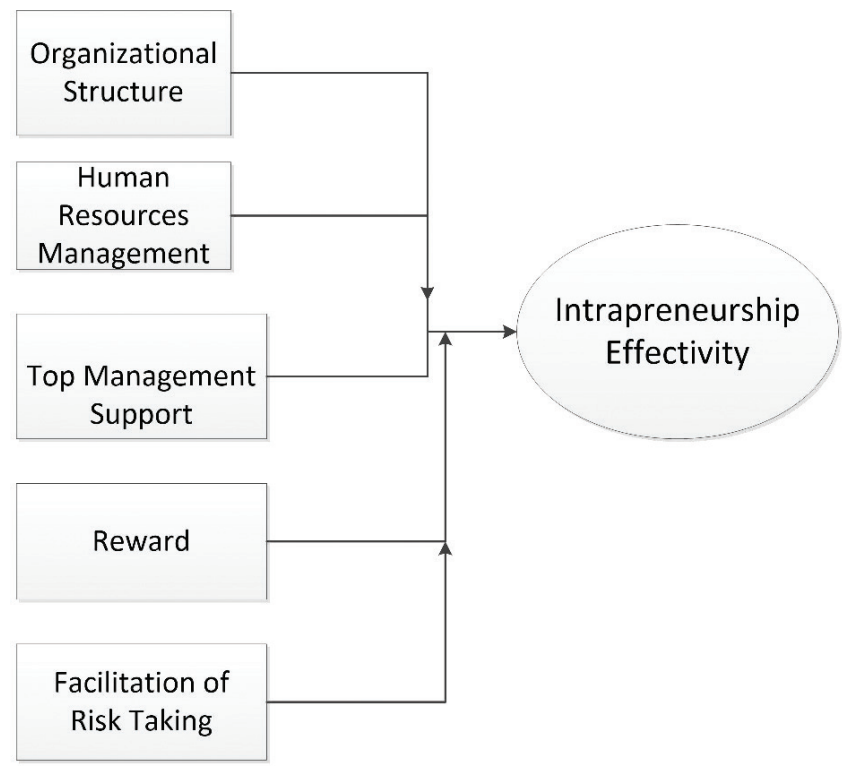

Figure 1: Intrapreneurship drivers
The above intrapreneurship drivers are described in the following diagram, which guides the study as a theoretical framework.

\section{Method}

This research used a qualitative approach by performing a descriptive case study to examine drivers and the implementation of intrapreneurship practices. The research object was PVI, a company with three subsidiaries that provides property-related services. PVI is part of a conglomerate with construction, property, mining, automotive parts, and TV media business. PVI's managers' attempts at intrapreneurship are both a phenomenon, and a context studied (Yin, 2009) by interpreting verbal information from participants. Although it is hoped that the study will explore ideas and develop theories, the results are not intended to be generalized.

\subsection{Data Collection and Analysis}

Preliminary data was collected through observation and informal discussion with several PVI employees. The primary data was obtained through semi-structured interviews with participants with specific criteria, such as a minimum work period of one year, and who have been involved in an intrapreneurship project. The participants were four males comprising two managers, one head of the division, and one director (see Table 1). All participants had been involved in carrying out the PVI intrapreneurship strategy directed by the top management. The concept of intrapreneurship driving factors from Hornsby et al. (2009) was used as an interview guide.

Table 1: Participants' brief profile

\begin{tabular}{|l|c|c|c|l|}
\hline No & Participant & $\begin{array}{c}\text { Age } \\
\text { (Years } \\
\text { old) }\end{array}$ & $\begin{array}{c}\text { Working } \\
\text { period } \\
\text { (Years) }\end{array}$ & $\begin{array}{c}\text { Division/ } \\
\text { Department }\end{array}$ \\
\hline 1 & YM & 39 & 10 & $\begin{array}{l}\text { System } \\
\text { Procedure \& } \\
\text { Internal Audit } \\
\text { Manager }\end{array}$ \\
\hline 2 & YI & 29 & 1 & $\begin{array}{l}\text { Human } \\
\text { Resources } \\
\text { Manager }\end{array}$ \\
\hline 3 & Al & 48 & 3 & $\begin{array}{l}\text { Property } \\
\text { Management } \\
\text { Division Head }\end{array}$ \\
\hline 4 & MA & 44 & 12 & Director \\
\hline
\end{tabular}




\section{Results}

Probing questions were used to explore further and obtain more accurate information. To validate the data, the study used triangulation by asking one expert and one practitioner who had information about the company's initiatives. Secondary data, such as annual reports and meeting minutes, were also used. The analysis was carried out by coding and classifying the text in the appropriate category for analysis purposes. The theme development was conducted using a start-list approach by utilizing existing concepts (Bradley, Curry, \& Devers, 2007)

\subsection{Brief Background of The Company}

PVI was founded in 2007 and now has three subsidiaries with approximately 4,000 employees (mostly outsourced). These three companies have different types of management and market. PTM's primary business is to serve the property management business, which includes office management, engineering/maintenance service, and security management. The other company, PPM, involves facility management types of business, which include housekeeping, pest control, landscaping, cleaning service, office support, and food and beverage management. The next company, PLM, serves parking management types of businesses. All of these subsidiaries are headed by a division head. The vision of the company is "To become a good total asset management company, with a focus on providing extraordinary results for clients". Meanwhile, the mission consists of three main aspects: 1) assisting clients in managing property and accelerating success; 2) developing business through community development; and 3) continue to grow sustainably by satisfying customers, motivating employees, improving processes, and optimizing resources.

\subsection{Intrapreneurship Initiatives at PVI}

From the general question, "Please explain in general your views on how PVI applies intrapreneurship," participants revealed that intrapreneurship initiatives at PVI are still highly limited, particularly in business development initiatives. The implementation is more on the development of innovation or strategic entrepreneurship where innovation is found in at least in the products offered or in the process of employee work. Even though top management provides freedom for employees to innovate, many employees still use conventional approaches and ways of thinking within the company. Almost all participants agreed that PVI required an intrapreneurship strategy, but regarding what company practices need improvement, YM stated:

"With the development and growth of businesses, PVI needs breakthroughs and innovations in developing business.
Only in that way can we generate new ideas and strategies in doing business in the company, and can even create new businesses."

Participant YI informed that the intrapreneurship initiative was implemented in the form of developing a working system through developing a human resource management information system. Similarly, participant AI specified intrapreneurship initiatives that have been implemented in the property management division which are as follows:

"Some of the intrapreneurship initiatives that have been carried out in the property management division includes implementation of a Web-based monitoring system (called "Sapujagad") and an android application. This system has been initiated by the top management for a long time but has only been implemented in the last 1.5 years. Next is the Web-based complaint handling system, which integrates the outsourcing manager and vendor; and then, implementation of the Human Resources Management System (HRMS) for human resources and implementation of Web-based management reports".

The Web-based monitoring system project led by participant AI and his team helps to make company work activities more efficient. This application is used as a substitute for a work checklist that was previously performed manually using paper. The use of this monitoring system can make it easier for supervisors, managers, or clients to check whether the planned work has been executed properly.

The HRMS is another intrapreneurship initiative that is considered to be quite successful, in which the three study participants involved worked together with external vendors. This system is used for the human resources division to store detailed employee data, including the compensation and benefits system (payroll, allowances, insurance, employee loans, etc.), and recruitment (to simplify the data input process of prospective employees, including outsourced). The system then integrates the data into several HRM purposes.

Another intrapreneurship project suggesting the application of intrapreneurship is a Web-based management reporting system. In this project, participant AI was involved with the company's IT team. This system allows representative offices to send up-to-date reports to the head office. This system not only saves work and equipment used but also allows the monitoring and reporting process to be done in a shorter time. An important feature of this reporting system is the complaint handling system, which was originally developed due to government sector client needs. This client was Bank Indonesia, a large government service organization. With this system, all issues experienced by a user can be addressed and handled immediately so that the company can improve its services. 


\subsection{Management Support and Leadership}

Participants YI and AI noted that support from management must improve. Participant YM stated:

"Support in the form of freedom to research, creating new technologies, implementing benchmark, utilizing human resources were OK in general." "We are also given the freedom to add any parameters needed in the field to be included in the application, based on the results of a survey of users. The implementation of benchmark uses standards for the hospitality business grooming, but the process needs further improvement".

Intrapreneurs must be able to approach or convince top management so that they can gain support and even be able to receive new ideas in the face of challenges (Hornsby, Kuratko, \& Zahra, 2002). Conversely, the role of top management is significant to ensure the company takes advantage of available opportunities and always supervises these activities to ensure that it remains in line with the company's vision and mission (Kuratko, 2007). Human resource support is considered insufficient because the management avoids providing skillful personal due to financial reasons. Top management prefers to use existing employees to carry out specific activities outside of their ongoing business. The three participants perceived that financial support was lacking and, in many situations, may hinder the project's advancement. One participant observed:

"Application development certainly has financial consequences, and often this hinders the development such as delay in completion. The need for experts also requires companies to spend additional investment. We are only asked to use existing personnel."

Even so, participants consider that top management tends to be open to receiving new inputs or ideas. Of the various intrapreneurship initiatives carried out at PVI, the three participants agreed that top management's leadership style has affected intrapreneurship initiatives in the company. YM stated the following:

"Intrapreneurship initiatives are closely related to leadership. It is also an important element as it involves the ability to make decisions, develop a culture and spirit for its employees to express new ideas, and implement them."

Participant YI added that leadership and culture in the company must quickly adapt to the situations' dynamics. Companies can make the most of current opportunities to develop a competitive advantage (Covin \& Slevin, 2008) and design an organization that ensures a culture, structure, resources, and systems that emphasize intrapreneurship, reflecting the entrepreneurial vision of the company. Thornberry (2006) suggests that entrepreneurial leaders must view work from an entrepreneurial perspective to assist managers in making decisions quickly and accurately. An encouraging vision and intrapreneurship organizational design require employee creativity to accept risks, be full of energy, willing to pursue opportunities and be able to accept innovative ideas.

\subsection{Limited Rewards for Intrapreneurship}

The rewards given to employees, including those involved in intrapreneurship projects, are perceived as insufficient to support entrepreneurial behavior. Even though a bonus program is available for the target achievements, its general nature is only based on the job description and not on the success of implementing the intrapreneurship project. A participant hopes that the rewards can be more specific to the intrapreneurship attempts:

"If the company needs to grow, survive, and sustain, and the new ideas or new business ideas from the division head/ manager are successfully implemented, it makes sense if the reward is special. It will make and foster a good business and provide jobs for people needed."

Such an expectation is sensible because the challenges faced by the team, both in developing recruitment applications and HRMS as intrapreneurship initiatives, are relatively high. Managers are asked to prepare application modules according to the user's needs. The company's concern about financial condition also worsens the reward aspect. For example, the benchmarking strategy was no longer implemented due to financial limitations.

"Previously, we were facilitated on benchmarking activity to Malaysia, Singapore, and even to Dubai. But recently, the program was canceled, apparently because of financial problems."

\subsection{Organizations That Support Intrapreneurship}

The influence of organizational structure can vary depending on the size, age of the organization, products, processes, and technology used (Miles \& Covin, 2002). Participants understood the importance of maximizing the advantages of ongoing business and utilizing these advantages to make intrapreneurship projects successful (Govindarajan \& Trimble, 2010). The issue of delegation and bureaucracy are the key points here. Tasks cannot be delegated to any employee because not all employees are qualified to carry out intrapreneur activities. Participant AI shared their experiences in developing the "Sapu Jagad" application: 
"Without delegation, it is impossible for us to finish this application on time." Participant AI completed this project in a matter of months. Applications that were originally only for cleaning service work, can also be used in engineering and parking services."

The most formidable challenge faced by the organization is the lack of human resources, who are experts in the field being developed. Fortunately, support in the form of training is perceived to be sufficient. IT staff have been given programming training from external parties so that Web and android-based application development can be substantially improved in the future. Also, the bureaucracy in the company was considered to be sufficiently supportive. Top management is supposed to provide an appropriate level of freedom to the division head in making decisions. Participants YM and YI agreed:

"Except for high-risk decision making, which we leave it to top management, if there are obstacles or the risks are too big, we can measure it ourselves."

Sufficient authority helps intrapreneurs convey and carry out their ideas to innovate (Amir, 2016) and facilitates them during times of limited resources.

\subsection{Relationship with Project Organization}

The three participants had similar views regarding the relationship between the existing organization and the project organization. Project organizations still depend on existing organizations in carrying out their innovation projects as well as in the use of existing employees and other existing facilities in the company.

"The existing organization and the project organization is mutually supportive because the project organization is built based on existing business resources, even if there is a new business, the project organization has been well prepared by the PIC from the existing organization."

Intrapreneurship activities at PVI have a link between existing organizations and project organizations. Participant AI participants evaluated that the relationship between the existing organization and the project organization was relatively well-controlled, and the nature of the partnership was quite prominent (Govindarajan \& Trimble, 2010). The nature of this partnership facilitates the intrapreneurship project to be harmonious in interacting with existing businesses, and not with a competitive attitude. Moreover, the management has chosen a policy to prioritize existing staff rather than recruiting new employees. What benefits from this choice is that employees already know each other and are used to working together. YM stated:
"Friends in the HR division are quite active in assisting the development process because if HR does not support the implementation of HRMS it will be hampered, and it is likely that the completion will be beyond the target deadline."

The good relationship is the hallmark of the property group holding of this conglomerate company. PVI also has a similar relationship with the holding company that oversees it. Often, these holding companies are involved in meeting resource needs, both human and financial. One participant remembered:

"We have a good relationship with the holding company. On several occasions, we are supported by an expert in public relations who help us managing the advertisement and arranging the annual company events (such as awards for the best employees and breaking the fast together). They are more experienced in dealing with the media and external companies."

\section{Discussion}

The data obtained from this work demonstrate that the dominant form of intrapreneurship effected by PVI is the development of new approaches to the work process, instead of new business development (Kuratko \& Morris, 2018). Other forms of development, such as spinoffs, new market developments, and joint ventures, are still limited. From the perspective of how the company transformed itself compared to before effecting the intrapreneurship project, it was found that the company only involves internal processes and products. Relative to the industry, the novelty that results from intrapreneurship efforts is not significant because the practices are unexceptional. Certain aspects are interesting to discuss from the results: Understanding of the intrapreneurship process, leadership and employee mindset, limited rewards and training, and flexibility.

\section{Creating an understanding of the Intrapreneurship}

Intrapreneurship implementation requires a complete understanding and acceptance of the employees and can be viewed as a company strategy. Similarly, the top management must see all intrapreneurship activities from a realistic perspective and be strongly committed to implementing these activities. The management of PVI needs to change the mindset of employees and convince them that becoming more creative and innovative at work are imperative to win against the competition. Chiang (2014) proposes that the dynamic of competition affects intrapreneurship activities positively, and mindset changing requires special attention. PVI needs a substantially larger campaign to change employees' mindsets about intrapreneurship strategies by presenting an aspirational but easy-to-understand business plan. A good plan communication is also necessary to build the awareness that a company can survive and grow if it actively creates and realizes business opportunities. 


\section{Entrepreneurial leadership and employee mindset}

The success of intrapreneurship initiatives requires leaders who encourage employees to express new ideas and realize them. An intrapreneurial leadership style enables organizations to adapt to all existing situations to make breakthroughs and innovations in business (Kuratko $\&$ Morris, 2018). With the development of technology, the dynamics of business competition, consumer demands, etc. will also develop. Leadership in PVI is considered to be sufficient to encourage breakthroughs and innovations in technology that ultimately improve work processes and become a resource to create new markets. PVI's top management is perceived to be quite concerned with business development, winning in competition, increasing customer satisfaction, and overcoming limited resources at work. Leaders must be actively involved in encouraging employees to innovate and play a role in supporting innovative ideas and providing the necessary resources to carry out intrapreneurial activities (Hornsby et al., 2009). Moreover, the implementation of intrapreneurship activities is expected to change the mindset of employees to be more innovative. The data and validation from the expert and practitioners suggest that several employees were unable to implement intrapreneurship in their work processes because they could not keep up with the increasingly advanced times and the higher demands of higher market competition.

\section{Limited rewards and training}

Apart from the employees' limited competency, the absence of a reward system that supports entrepreneurial activity is another factor that makes some employees reluctant to carry out intrapreneurship (Tang et al., 2015). Rewards in the form of annual bonuses are available but only limited to the job description-based achievements, not reflecting the implementation of intrapreneurship (Montoro-Sanchez \& Ribeiro Soriano, 2011). Rewards based on innovativeness, which provides challenges and is tolerant of risk, have not yet been implemented. In addition to rewards, reinforcement from top management is also required. PVI's top management is quite helpful in intrapreneurship by providing ideas, policies, advice, and challenges. Top management also opens communication to subordinates to capture new ideas. Ideas and innovations are not only created from top to bottom but can also come from the bottom. Updates can arise from anywhere; hence, the freedom to communicate directly with subordinates is an advantage (Amabile \& Kramer, 2011). Education and training on innovation are also particularly necessary to assist employees in carrying out their duties (North, 2015). There is limited training with content that leads explicitly to intrapreneurship, and companies still only focus on product knowledge, grooming skills, and other training that is intended to create customer satisfaction.

\section{Flexibility}

Intrapreneurship activities also require flexibility, including in time utilization. Currently, the support provided by top management in PVI is still considered to be insufficient. Hornsby et al. (2009) revealed that workload evaluation must ensure that employees who are assigned to carry out intrapreneurship have sufficient time and are aligned with the achievement of the company's long- and short-term goals. Providing freedom for the head/manager division in distributing tasks to subordinates and adding internal human resources or forming a temporary task force team is a plus. Division heads or managers are also required to have the ability to appropriately divide tasks among their subordinates.

\section{Intrapreneurship and devolved management}

The success of intrapreneurship demands a conducive approach to decentralized authority, participation, and cooperation. Tang (2015) found a strong relationship between devolved management, which emphasizes empowerment and autonomy with corporate entrepreneurship. An effective delegation of tasks is supported by an organizational structure that can facilitate distributing duties and responsibilities between departments and positions. In PVI, all intrapreneurship activities are assigned to existing employees. Therefore, these employees must maintain excellence in the ongoing business and intrapreneurship activities (Govindarajan \& Trimble, 2010). However, often, the existing employees are resistant because apart from having to implement intrapreneurship activities, they also have to execute routine activities. Moreover, because the reward provided is not in line with the intrapreneurship strategy, many employees perceive that their workload exceeds the limit, lowering their motivation to develop innovation. Top management practices are empowering employees by trusting internal employees and avoiding the recruitment of new employees. This action is effective only if the available human resources have sufficient capacity. Empowerment can succeed if employees have specific competencies and understand the organization's ultimate goals. In the HRMS development project, the existing employees considered their main job a priority. This perception is problematic and makes the project slow. The HR division often finds it difficult to allocate time between the main job and the HRMS development process. This complication causes the work to fall behind the schedule. Concerning the freedom of decision-making, division heads have the authority to act more creatively without being hindered by limited resources.

\subsection{Practical Implications}

The application of intrapreneurship as a strategy requires understanding and commitment from all parties in the organization. This condition will lead to entrepreneurial 
behavior from all parties in seizing opportunities and being more competitive. Morris, Kuratko, and Covin (2011) noted that for this strategy to be successful, the initiatives must be integrated with the company's overall strategy. The drive for intrapreneurship needs to be supported by the development of a robust entrepreneurial culture. Although leaders have an entrepreneurial outlook and support related endeavors, companies must build an entrepreneurial culture through various modes. Companies can perform comprehensive and periodic measurements of these driving factors using available tools, such as the Corporate Entrepreneurship Assessment Instrument (CEAI) model (Kuratko, Hornsby, \& Covin, 2014) and then designing the development program.

Employee competency is a substantial issue at PVI. Although leadership, empowerment, and delegation of authority are considered to be sufficient, employee competencies must be improved. The HR department should modify recruitment, training, performance evaluation, and the reward system to align with the entrepreneurial spirit. Many organizational studies show that increased motivation can enable employees to accept given responsibilities. This attempt will ultimately provide a strong sense of growth and work motivation to handle intrapreneurship projects (Tang et al., 2015). Apart from HR training, the communication skills required to express ideas and political skills must be addressed.

The need for political skills to ensure that new ideas are accepted and supported is an essential part of innovation studies (Tang et al., 2015). A manager may have sound business acumen, but to obtain the necessary backup from related parties, particularly top management, political skills are essential. Intrapreneur managers need political skills to influence parties in supporting resource allocation to achieve intrapreneurship goals. Managers also need to use their insights and access to various authorities to influence people.

\subsection{Limitation and Future Studies}

This study has several limitations to be considered in future studies. First, we only relied on one sub-holding company with three subsidiaries. Although generalization is not the primary goal of this study, it would be better if future research also studies organizations in different industries with varying institutional contexts. Second, participants were only taken from internal companies, whereas the experiences or views of participants from other industries may provide different perspectives. Third, additional best practice benchmarking information is necessary to address the gaps in intrapreneurship practices. Fourth, the multi-firm context seems interesting for further analysis. Following the study of collaborative entrepreneurship (Ratten, 2014), the condition of a company amid various companies in a conglomerate group with multiple businesses can be an opportunity for existing services.

\section{Conclusions}

This study provides highly useful information regarding the application of intrapreneurship for business development in an established company and part of a multi-firm conglomerate. It provides insight into the application of intrapreneurship in the Indonesian context, particularly in the property services industry. More importantly, we propose that intrapreneurship initiatives are less likely to succeed if they are not supported by developing a more systematic entrepreneurial mindset, behavior, and culture.

PVI has limitations in its intrapreneurship practice because it is implemented in developing new approaches for working processes, but not in developing new businesses. Some of the dominant intrapreneurship driving factors are top management support, flexibility in time, management of existing organizational relationships, and intrapreneurship projects. On the other hand, driving factors such as rewards and the capacity and entrepreneurial behavior of human resources, as well as HRM practices, are still relatively limited. The program for institutionalizing the intrapreneurship vision and strategy, developing entrepreneurial capacity, and benchmarking best practices, both from the property industry and from other sectors, are required as references. Therefore, companies' HR practices also need to adjust to the increased pressure being placed on achieving entrepreneurial goals. Exploration and further capitalizing the position of PVI and its property holding company as part of the conglomerate group is also necessary because there are many business opportunities and support within the group's internal environment.

\section{References}

Alpkan, L., Bulut, C., Gunday, G., Ulusoy, G., \& Kilic, K. (2010). Organizational support for intrapreneurship and its interaction with human capital to enhance innovative performance. Management Decision, 48(5), 732-755. https:// doi.org/10.1108/00251741011043902

Amabile, T. M., \& Kramer, S. (2011). The progress principle: Using small wins to ignite joy, engagement, and creativity at work. Boston, MA: Harvard Business School Press.

Amir, M. T. (2015). Entrepreneurial behavior and innovative behavior: A conceptual clarification. The Asian Journal of Technology Management, 8(2), 161-172. https:/doi. org/10.12695/ajtm.2015.8.2.7

Amir, M. T. (2016). Corporate entrepreneurship \& innovation. Jakarta, Indonesia: Prenada Media Group.

Amir, M. T. (2017). Intrapreneurship drivers in an established organization: Case study in property business. In The 2nd Indonesia International Conference on Science Technology Park (IICSTP). Jakarta, Indonesia.

Bradley, E. H., Curry, L. A., \& Devers, K. J. (2007). Qualitative data analysis for health services research: developing 
taxonomy, themes, and theory. Health Services Research, 42(4), 1758-1772. https://doi.org/10.1111/j.1475-6773.2006.00684.x

Burgers, J. H., Jansen, J. J. P., Van den Bosch, F. A. J., \& Volberda, H. W. (2009). Structural differentiation and corporate venturing: The moderating role of formal and informal integration mechanisms. Journal of Business Venturing, 24(3), 206-220. https://doi.org/10.1016/j.jbusvent.2009.01.006

Chiang, L. L. (2014). An evaluation of the levels of entrepreneurship and competitive advantages in small midwestern agritourism businesses. Doctorate Dissertation, Iowa State University. https://doi.org/https://doi.org/10.31274/etd-180810-3568

Choi, J. N., \& Price, R. H. (2005). The effects of personinnovation fit on individual responses to innovation. Journal of Occupational \& Organizational Psychology, 789(1), 83-96. https://doi.org/10.1348/096317904X22953

Covin, J. G., \& Miles, M. P. (1999). Corporate entrepreneurship and the pursuit of competitive advantage. Entrepreneurship Theory and Practice, 23(3), 47-47.

Covin, J. G., \& Slevin, D. P. (2008). The entrepreneurial imperatives of strategic leadership. In: M. A. Hitt, R. D. Ireland, S. M. Camp, \& D. L. Sexton (Eds.), Strategic entrepreneurship: Creating a new mindset (pp.309-327). Oxford, UK: Blackwell Publishers.

Dess, G. G., Lumpkin, G. T., \& Mcgee, J.E. (1999). Linking corporate entrepreneurship to strategy, structure, and process: Suggested research directions. Entrepreneurship Theory and Practice, 23(3), 85-102. https://doi.org/10.1177/104225879902300306

Do, D. T., Nguyen, T. H., Nguyen, T. H. N., Ha, H. H., \& Le, T. T. (2020). The influence of leadership style on accountants' commitment with enterprise: An empirical study on Vietnamese FDI Firms. Journal of Asian Finance, Economics and Business, 7(3), 235-243. https://doi.org/10.13106/jafeb. 2020.vol7.no3.235

Fakir, A. N. M. A., \& Jusoh, R. (2020). Board gender diversity and corporate sustainability performance: Mediating role of enterprise risk management. Journal of Asian Finance, Economics and Business, 7(6), 351-363. https://doi. org/10.13106/jafeb.2020.vol7.no6.351

Govindarajan, V., \& Trimble, C. (2010). The other side of innovation: Solving the execution challenge. Boston MA: Harvard Business School Press.

Hornsby, J. S., Kuratko, D. F., Shepherd, D. A., \& Bott, J. P. (2009). Managers' corporate entrepreneurial actions: Examining perception and position. Journal of Business Venturing, 24(3), 236-247.

Hornsby, J. S., Kuratko, D. F., \& Zahra, S. A. (2002). Middle managers' perception of the internal environment for corporate entrepreneurship: Assessing a measurement scale. Journal of Business Venturing, 17(6), 253-273.

Ireland, R. D., Hitt, M. A., \& Sirmon, D. G. (2003). A model of strategic entrepreneurship: The construct and its dimensions. Journal of Management, 29(6), 963-989. https:// doi.org/10.1016/S0149-2063(03)00086-2
Jumasseitova, A. K., \& Potluri, R. M. (2020). Exploratory research on entrepreneurial ecosystems: effects on economic integration. Journal of Asian Finance, Economics, and Business, 7(8), 661-670. https://doi.org/10.13106/jafeb.2020. vol7.no8.661

Kuratko, D. F. (2007). Entrepreneurial leadership in the 21st century. Journal of Leadership \& Organizational Studies, 13(4), 1-11. https://doi.org/10.1177/10717919070130040201

Kuratko, D. F., \& Audretsch, D. B. (2009). Strategic entrepreneurship: Exploring different perspectives of an emerging concept. Entrepreneurship Theory and Practice, 33(1), 1-17. https://doi.org/10.1111/j.1540-6520.2008.00278.x

Kuratko, D. F., Hornsby, J. S., \& Covin, J. G. (2014). Diagnosing a firm's internal environment for corporate entrepreneurship. Business Horizons, 57(1), 37-47. https://doi.org/10.1016/j. bushor.2013.08.009

Kuratko, D. F., \& Morris, M. H. (2018). Corporate entrepreneurship: A critical challenge for educators and researchers. Entrepreneurship Education and Pedagogy, 1(1), 42-60. https://doi.org/10.1177/2515127417737291

Logahan, T., \& Jerry, M. (2014). Analysis of the influence of intrapreneurship and leadership on employee job satisfaction. Universitas Bina Nusantara.

McGrath, R. G., \& McMillan, I. C. (2000). The entrepreneurial mindset: Strategies for continuously creating opportunities in an age of uncertainty. Boston, MA: Harvard Business School Press.

Miles, M.P., \& Covin, J. G. (2002). Exploring the practice of corporate venturing: some common forms and their organizational implications. Entrepreneurship: Theory and Practice, 26(3), 21-41. https://doi.org/10.1177/104225870202600302

Montoro-Sanchez, Á., \& Ribeiro Soriano, D. (2011). Human resource management and corporate entrepreneurship. International Journal of Manpower. 32(March), 6-13 https:// doi.org/10.1108/01437721111121198

Morris, M. H., Kuratko, D. F., \& Covin, J. G. (2011). Corporate entrepreneurship \& innovation (3rd ed.). Boston, MA: Cengage Learning.

North, J. J. (2015). Individual Intrapreneurship in Organisations: A New Measure of Intrapreneurial Outcomes. Doctorate Dissertation, University of New York.

Phan, P. H., Wright, M., Ucbasaran, D., \& Tan, W. L. (2009). Corporate entrepreneurship: Current research and future directions. Journal of Business Venturing, 24(3), 197-205. https://doi.org/10.1016/j.jbusvent.2009.01.007

Ratten, V. (2014). Encouraging collaborative entrepreneurship in developing countries: The current challenges and a research agenda. Journal of Entrepreneurship in Emerging Economies, 6(3), 298-308. https://doi.org/10.1108/JEEE-05-2014-0015

Sathe, V. (2007). Corporate entrepreneurship: top managers and new business creation. Cambridge, England: Cambridge University Press. 
Sharma, P., \& Chrisman, S. J. (2007). Toward a reconciliation of the definitional issues in the field of corporate entrepreneurship. In: P. Sharma, \& S. J. J. Chrisman (Eds.), Corporate entrepreneurship (pp. 83-103). Berlin, Germany: Springer.

Tang, G., Wei, L. Q., Snape, E., \& Ng, Y. C. (2015). How effective human resource management promotes corporate entrepreneurship: Evidence from China. The International Journal of Human Resource Management, 26(12), 1586-1601. https://doi.org/10.1080/09585192.2014.953973
Thornberry, N. E. (2006). Lead like an entrepreneur: Keeping the entrepreneurial spirit alive within the corporation. New York, NY: McGraw Hill Companies .

Yang, Y., Narayanan, V. K., \& Zahra, S. (2009). Developing the selection and valuation capabilities through learning: The case of corporate venture capital. Journal of Business Venturing, 24(3), 261-273. https://doi.org/10.1016/j.jbusvent.2008.05.001

Yin, R. K. (2009). Case study research: Design and methods (4th ed.). Thousand Oaks, CA: Sage Publications. 